\title{
Effect of Tillage and Sources of Nutrient on Direct Seeded Sali Rice
}

\author{
Nilotpal Hazarika* and M.K. Sarmah \\ Department of Agronomy, Assam Agricultural University, Jorhat-785013, Assam, India \\ *Corresponding author
}

\section{A B S T R A C T}

\section{Keywords}

Direct seeded rice, Minimum tillage, Zero tillage, Conventional tillage, Vermicompost, Enriched compost.

\section{Article Info}

Accepted:

15 September 2017

Available Online:

10 November 2017
A field experiment was conducted at Instructional-cum-Research (ICR) farm, Assam Agricultural University, Jorhat during 2016. The experiment was laid out in split-plot design with three replications. The treatments consisted of three different tillage practices in main plots viz., minimum tillage $\left(\mathrm{T}_{1}\right)$, zero tillage with non-selective herbicide (Glyphosate) $\left(\mathrm{T}_{2}\right)$ and conventional tillage $\left(\mathrm{T}_{3}\right)$ along with sources of nutrient recommended doses of fertilizer $\left(\mathrm{F}_{1}\right) 60: 20: 40 \mathrm{~N}: \mathrm{P}_{2} \mathrm{O}_{5}: \mathrm{K}_{2} \mathrm{O} \mathrm{kg} / \mathrm{ha}, 50 \% \mathrm{~N}$ replacement through Vermicompost $+50 \%$ RDF of $\mathrm{N}$ and full RDF of $\mathrm{P}_{2} \mathrm{O}_{5}$ and $\mathrm{K}_{2} \mathrm{O}\left(\mathrm{F}_{2}\right)$ and $50 \% \mathrm{~N}$ replacement through Enriched compost $+50 \%$ RDF of $\mathrm{N}$ and full RDF of $\mathrm{P}_{2} \mathrm{O}_{5}$ and $\mathrm{K}_{2} \mathrm{O}$ $\left(\mathrm{F}_{3}\right)$ in sub plots. The results of the experiment revealed that growth characters of rice were significantly influenced by different tillage treatments. Conventional tillage recorded significantly higher growth and yield attributing characters. Conventional tillage also recorded significantly higher grain yield $(42.81 \mathrm{q} / \mathrm{ha})$ and straw yield $(71.83 \mathrm{q} / \mathrm{ha})$ over other tillage practices. The INM treatment receiving $50 \% \mathrm{~N}$ replacement through Enriched compost $+50 \%$ RDF of $\mathrm{N}$ and full RDF of $\mathrm{P}_{2} \mathrm{O}_{5}$ and $\mathrm{K}_{2} \mathrm{O}$ shown its superiority in regards to growth and yield attributing characters of rice. The grain yield $(38.26 \mathrm{q} / \mathrm{ha})$ as well as straw yield $(66.66 \mathrm{q} / \mathrm{ha})$ obtained in this treatment were significantly higher than other treatments.

\section{Introduction}

Rice is the main cereal crop in Assam's agriculture as it is the main diet of people of the state. Assam is traditionally a rice growing area. Rice plays a pivotal role in the socio-cultural life of the people of the state. The crop is grown in a diverse situation in Assam. Direct seeding methods have several advantages over transplanting. In addition to higher economic returns, direct seeded rice crops are faster and easier to plant, less labour intensive and consume less water (Bhushan et al., 2007) are conducive to mechanisation (Khade et al., 1993), generally flower earlier leading to shorter crop duration (Farooq et al., 2006a, b) and mature 7-10 days earlier and have less methane emissions (Pandey and Velasco, 1999) than transplanted rice. Typically, direct seeded rice is established earlier than transplanted rice without growth delays from transplant injury; which hastens physiological maturity and reduces vulnerability to late-season drought (Tuong et al., 2000).

The labour scarcity is being felt as a major impediment in agriculture. Hence direct seeded rice crop can be grown to solve the problem of labour scarcity. 
Tillage systems influences physical, chemical and biological properties of soil and have a major impact on soil productivity and sustainability. Appropriate tillage practices avoids the degradation of soil properties but maintains crop yields as well as ecosystem stability. Tillage operations improve the physical condition by manipulating and pulverization of the soil which provides suitable environment to the crop for proper growth and development.

Integrated nutrient management is the combined application of chemical fertilizers along with organic materials for sustaining the desired crop productivity through optimization of benefits from all possible sources of plant nutrients in an integrated manner. It is ecologically, socially and economically viable and environmental friendly.

\section{Materials and Methods}

The experiment was carried out during kharif season of 2016 in the Instructional-cum Research (ICR) Farm of Assam Agricultural University, Jorhat. A well-drained medium land was selected for carrying out the experiment. The soil was sandy loam in texture, acidic in reaction. The climate of Jorhat, as a whole is sub- tropical humid with hot summer and cold winter. The experiment was laid out in split plot design with three replications. The experiment included the possible combinations of 3 tillage practices viz., Minimum tillage, Zero tillage with nonselective herbicide (Glyphosate) and Conventional tillage in the main plots and source of nutrients viz., recommended doses of fertilizer (RDF), $50 \% \mathrm{~N}$ replacement through Vermicompost $+50 \%$ RDF of $\mathrm{N}$ and full $\mathrm{RDF}$ of $\mathrm{P}_{2} \mathrm{O}_{5}$ and $\mathrm{K}_{2} \mathrm{O}$ and $50 \% \mathrm{~N}$ replacement through Enriched compost + $50 \% \mathrm{RDF}$ of $\mathrm{N}$ and full $\mathrm{RDF}$ of $\mathrm{P}_{2} \mathrm{O}_{5}$ and $\mathrm{K}_{2} \mathrm{O}$ in the sub plots. Rice variety $T T B-404$ at the seed rate of $75 \mathrm{~kg} /$ ha were dry seeded on 23 May, 2016 in the research plots. The sowing was done manually by placing the seeds at $4-5 \mathrm{~cm}$ depth in the furrows opened at $20 \mathrm{~cm}$ apart. The seeds were covered with a thin layer of soil and pressed firmly. Recommended doses of fertilizer 60:20:40 as $\mathrm{N}: \mathrm{P}_{2} \mathrm{O}_{5}: \mathrm{K}_{2} \mathrm{O}$ in $\mathrm{kg} / \mathrm{ha}$ were applied in the form of Urea, SSP and MOP, respectively to the rice crop as per treatment. Vermicompost and Enriched compost were applied in the respective treatments. Required quantities of Nitrogen, Phosphorus and potassium through Urea (46\% N), Single Super Phosphate (16\% $\left.\mathrm{P}_{2} \mathrm{O}_{5}\right)$ and Muriate of Potash $\left(60 \% \mathrm{~K}_{2} \mathrm{O}\right)$ were applied as basal application in combination with Vermicompost and Enriched compost. For RDF, Nitrogen was applied in 3 split doses i.e., $1 / 2$ of $\mathrm{N}$ was applied in final land preparation, $1 / 4$ at active tillering stage and remaining $1 / 4$ at panicle initiation stage. All the phosphatic and potassic fertilizers were applied well ahead of sowing. The crop was harvested at maturity on 20 Oct, 2016. Harvesting of crop was done manually with sickle.

\section{Results and Discussion}

\section{Growth attributes}

Plant height, plant population $/ \mathrm{m}^{2}$ and dry matter accumulation $\left(\mathrm{g} / \mathrm{m}^{2}\right)$ of rice was significantly influenced by different tillage practices (Table 1). Rice grown in conventional tillage recorded the highest value in above characters which was statistically at par with minimum tillage and significant to zero tillage. This is due to tillage operations improve the physical condition by manipulating and pulverization the soil, which not only provides suitable environment to the germinating seeds and emerging seedlings, but also supplies free oxygen and availability of soil moisture and essential nutrients to plants and ultimately 
improve the above growth characters. These results are in close conformity with the findings of Arora et al., (1991).

Different tillage practices significantly affected the weed population $/ \mathrm{m}^{2}$. The highest weed population was found in zero tillage treatment which was significant to minimum tillage and conventional tillage. In zero tillage, weed seeds remain in the upper layer and immediately contribute to infestation. Similar results are reported by Arshad et al., (1995). In sources of nutrient plant height, plant population $/ \mathrm{m}^{2}$ and dry matter accumulation $\left(\mathrm{g} / \mathrm{m}^{2}\right)$ showed highest value in INM sources compared to RDF.

Table.1 Effect of tillage and sources of nutrient on growth attributes of rice

\begin{tabular}{|c|c|c|c|c|}
\hline Treatments & $\begin{array}{l}\text { Plant height } \\
\text { (cm) }\end{array}$ & $\begin{array}{c}\text { Plant } \\
\text { population } / \mathbf{m}^{2}\end{array}$ & $\begin{array}{c}\text { Dry matter } \\
\text { accumulation }\left(g / \mathrm{m}^{2}\right)\end{array}$ & $\begin{array}{c}\text { Weed } \\
\text { population } / \mathbf{m}^{2}\end{array}$ \\
\hline \multicolumn{5}{|l|}{ Main plot (Tillage) } \\
\hline Minimum tillage & 108.89 & 283.22 & 1147.19 & 16.01 \\
\hline $\begin{array}{llll}\text { Zero } & \text { tillage } & \text { with } & \text { non-selective } \\
\text { herbicides(glyphosate) } & & \\
\end{array}$ & 99.70 & 246.67 & 1090.70 & 22.54 \\
\hline Conventional tillage & 117.15 & 292.78 & 1204.00 & 11.34 \\
\hline S.Ed( $( \pm)$ & 3.30 & 7.92 & 20.10 & 1.61 \\
\hline $\mathrm{CD}(0.05)$ & 9.48 & 22.59 & 57.31 & 4.59 \\
\hline \multicolumn{5}{|l|}{ Sub plot (sources of nutrient) } \\
\hline Recommended dose of fertilizer (RDF) & 105.22 & 261.78 & 1104.11 & 16.27 \\
\hline $\begin{array}{l}50 \% \mathrm{~N} \text { replacement through Vermicompost }+50 \% \\
\text { RDF of } \mathrm{N} \text { and full RDF of } \mathrm{P}_{2} \mathrm{O}_{5} \text { and } \mathrm{K}_{2} \mathrm{O}\end{array}$ & 106.96 & 274.00 & 1128.33 & 16.91 \\
\hline $\begin{array}{l}50 \% \quad \mathrm{~N} \text { replacement through Enriched } \\
\text { compost }+50 \% \text { RDF of } \mathrm{N} \text { and full RDF of } \mathrm{P}_{2} \mathrm{O}_{5} \text { and } \\
\mathrm{K}_{2} \mathrm{O}\end{array}$ & 113.56 & 286.89 & 1209.45 & 16.70 \\
\hline S.Ed $( \pm)$ & 2.92 & 14.21 & 36.36 & 1.29 \\
\hline $\mathrm{CD}(0.05)$ & NS & NS & 80.10 & NS \\
\hline Interaction & NS & NS & NS & NS \\
\hline
\end{tabular}

NS=Non-significant

Table.2 Effect of tillage and sources of nutrient on yield attributes and yield of rice

\begin{tabular}{|c|c|c|c|c|c|}
\hline Treatments & $\begin{array}{l}\text { Number of } \\
\text { panicle/m }\end{array}$ & $\begin{array}{c}\text { Panicle } \\
\text { length }(\mathrm{cm})\end{array}$ & $\begin{array}{l}\text { Number of filled } \\
\text { grains per panicle }\end{array}$ & $\begin{array}{c}\text { Grain } \\
\text { yield(q/ha) }\end{array}$ & $\begin{array}{c}\text { Straw } \\
\text { yield(q/ha) }\end{array}$ \\
\hline \multicolumn{6}{|l|}{ Main plot (Tillage) } \\
\hline Minimum tillage & 213.11 & 25.00 & 107.33 & 38.19 & 65.82 \\
\hline Zero tillage with non-selective herbicides (glyphosate) & 203.89 & 23.31 & 97.96 & 25.39 & 49.29 \\
\hline Conventional tillage & 220.78 & 26.30 & 114.52 & 42.81 & 71.83 \\
\hline S.Ed( $( \pm)$ & 1.78 & 0.71 & 4.39 & 0.36 & 1.83 \\
\hline $\mathrm{CD}(0.05)$ & 5.06 & 2.03 & 12.51 & 1.03 & 5.22 \\
\hline \multicolumn{6}{|l|}{ Sub plot (Sources of nutrient) } \\
\hline Recommended dose of fertilizer (RDF) & 210.78 & 24.43 & 104.74 & 33.04 & 58.65 \\
\hline $\begin{array}{l}50 \% \mathrm{~N} \text { replacement through Vermicompost }+50 \% \mathrm{RDF} \\
\text { of } \mathrm{N} \text { and full RDF of } \mathrm{P}_{2} \mathrm{O}_{5} \text { and } \mathrm{K}_{2} \mathrm{O}\end{array}$ & 212.78 & 25.04 & 107.33 & 35.09 & 61.63 \\
\hline $\begin{array}{l}50 \% \mathrm{~N} \text { replacement through Enriched compost }+50 \% \\
\text { RDF of } \mathrm{N} \text { and full RDF of } \mathrm{P}_{2} \mathrm{O}_{5} \text { and } \mathrm{K}_{2} \mathrm{O}\end{array}$ & 214.22 & 25.15 & 107.74 & 38.29 & 66.66 \\
\hline S.Ed $( \pm)$ & 5.49 & 0.89 & 2.70 & 1.40 & 2.18 \\
\hline $\mathrm{CD}(0.05)$ & NS & NS & NS & 3.07 & 4.80 \\
\hline Interaction & NS & NS & NS & NS & NS \\
\hline
\end{tabular}

$\mathrm{NS}=$ Non-significant 
Among the INM sources, $50 \% \mathrm{~N}$ replacement through Enriched compost $+50 \%$ RDF of $\mathrm{N}$ and full RDF of $\mathrm{P}_{2} \mathrm{O}_{5}$ and $\mathrm{K}_{2} \mathrm{O}$ recorded the highest value in above characters due to favourable soil condition, soil fertility improvement in the presence of organic sources that resulted in higher moisture holding capacity and favourable uptake of nutrients. These results are in conformity with the findings of Zahir et al., (2007).

\section{Yield attributing characters and yield}

Yield and yield attributing characters of rice were significantly influenced by different tillage practices (Table 2). Conventional tillage recorded the highest grain and straw yield due to less number of weeds having no or decreased weed competition and minimum nutrient removal by weeds and thereby increased the capacity of nutrient uptake and enhanced the source and sink sizes which in turn increased the yield attributes viz., number of panicle $/ \mathrm{m}^{2}$, panicle length and filled grains per panicle. Saha and Rao (2010) also found similar type of findings in their study.

Among the different sources of nutrient, all the parameters related to yield attributes had been found non-significant.

The highest grain and straw yield were recorded with the application of $50 \% \mathrm{~N}$ replacement through enriched compost $+50 \%$ RDF of $\mathrm{N}$ and full RDF of $\mathrm{P}_{2} \mathrm{O}_{5}$ and $\mathrm{K}_{2} \mathrm{O}$ which was significant to other sources of nutrient.

This might be due to the fact that enriched compost could have provided required amount of available nutrients and improved chemical and biological environment resulting better growth and development in yield attributes that ultimately had reflected in grain and straw yield. Similar findings were also reported earlier Bora et al., (2014).

\section{References}

Arora, V. K., Gajra, P. R. and Prihar, S. S. (1991). Tillage effect on corn in sandy soil in relation to water retentivity, nutrient and water management and seasonal evaporability. Soil and Tillage Res., 21: 1-21.

Arshad, M.A., Gill, K.S. and Coy. G.R. (1995). Barley, Canola and weed growth with decreasing tillage in a cold, semiarid climate. Agron. J. 87: 49-55

Bhushan, L., Ladha, J. K., Gupta, R.K., Singh, S., Tirol-Padre, A., Saharawat, Y. S., Gathala, M. and Pathak, H. (2007). Saving of water and labor in a rice wheat system with no-tillage and direct seeding technologies. Agron. J. 99: 1288-1296.

Bora, D., Goswami, J., Saud, R. K. and Begum, M. (2014). Effect of organic inputs on production and quality of scented rice (Oryza sativa) variety keteki joha in Assam and its economic aspect. Agric. Sci. Digest. 34(2): 115118

Farooq, M., Basra, S. M. A. and Wahid, A. (2006a). Priming of field-sown rice seed enhances germination, seedling establishment, allometry and yield. Plant Growth Regul. 49: 285-294

Farooq, M., Basra, S.M.A., Tabassum, R. and Afzal, I. (2006b). Enhancing the performance of direct seeded fine rice by seed priming. Plant Prod. Sci. 9: 446-456.

Khade, V.N., Patil, B.D., Khanvilkar, S.A. and Chavan, L.S. (1993). Effect of seeding rates and level of $\mathrm{N}$ on yield of direct-seeded (Rahu) summer rice in Konkan. J. Maharash. Agric. Univ. 18: 32-35

Pandey, S. and Velasco, L.E. (1999). Economics of alternative rice establishment methods in Asia: a strategic analysis. In: Social Sciences 
Division Discussion Paper, Increasing water productivity and weed International Rice Research Institute, suppression of wet seeded rice: effect of Los Banõs, Philippines.

Saha S. and Rao, K.S. (2010). Evaluation of Bensulfuron-methyl for weed control in wet direct-sown summer rice. Oryza. 47(1): 38-41.

Tuong, T. P., Pablico, P.P., Yamauchi, M., Confesor, R. and Moody, K. (2000). water management and rice genotypes. J. Exp. Agric. 36: 1-19

Zahir, A. Z., Muhammad, N., Muhammad, Z., Khalid, A. and Muhammad, A. (2007). Enrichment of composted organic wastes for improving rice production. $J$. Chem. Soc. Pakistan, 29(5): 514-519.

\section{How to cite this article:}

Nilotpal Hazarika and Sarmah, M.K. 2017. Effect of Tillage and Sources of Nutrient on Direct Seeded Sali Rice. Int.J.Curr.Microbiol.App.Sci. 6(11): 1876-1880. doi: https://doi.org/10.20546/ijcmas.2017.611.223 